Przegląd Badań Edukacyjnych Educational Studies Review

ISSN 1895-4308

nr 23 (2/2016), s. 45-60

ORYGINALNE ARTYKUtY BADAWCZE

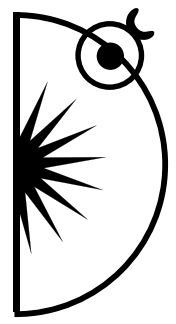

Beata Przyborowska

Uniwersytet Mikołaja Kopernika w Toruniu, e-mail: bprzybor@umk.pl

Violetta Kopińska

Uniwersytet Mikołaja Kopernika w Toruniu, e-mail: Violetta.Kopinska@umk.pl

Iwona Murawska

Uniwersytet Mikołaja Kopernika w Toruniu, e-mail: murawska@doktorant.umk.pl

\title{
Kompetencje społeczne i obywatelskie w edukacji szkolnej - pozór w podstawie programowej dla trzeciego etapu edukacyjnego*
}

http://dx.doi.org/10.12775/PBE.2016.072

\section{Social and Civic Competences in School Education - a Sham in Core Curriculum for School Students Aged 12/13 - 15/16}

\begin{abstract}
:
In this article we diagnose another sham in education. In this way, we are adding symbolically the next chapter to the book edited by Maria Dudzikowa and Karina Knasiecka-Falbierska "Sprawcy i/lub ofiary działań pozornych w edukacji szkolnej" [The Offenders and /or Victims of Shamming Actions in School Education] (this book was an inspiration for the text). Using the results of research on social and civic competences in the core curricula in school education, we concentrate on analyzing the core curriculum for gimnazjum (school for students aged 12/13-15/16). We conclude the semblance of the core curriculum's accordance

* Badanie przeprowadzone w ramach projektu Improving Teaching Methods for Europe (ImTeaM4EU). Projekt współfinansowany w ramach programu Unii Europejskiej Erasmus+ Partnerstwa Strategiczne. Badanie zostało przeprowadzone przez zespół badaczek z Katedry Pedagogiki Szkolnej Wydziału Nauk Pedagogicznych UMK.
\end{abstract}


to legal and political declarations. We note a huge dominance of the requirements relating to knowledge, and "deficits" in the range of specific, important skills and attitudes.

Keywords: middle school (gimnazjum), school, core curriculum, social competences, civic competences, educational policy

\section{Wprowadzenie}

Szkoła z jednej strony jest częścią świata zastanego (w którym przyszło jej funkcjonować), $z$ drugiej jednak sama świat ten stanowi i tworzy. Zawsze działa w określonym kontekście, dlatego trudno postrzegać ją wyłącznie jako odrębną i autonomiczną wobec swojego otoczenia. Szkoła stanowi część większej struktury, jest organizacją i instytucją, w której transmitowane są wartości danej kultury, a także odbywa się proces socjalizacji i wychowania (Schulz, 1992). Roman Schulz zauważa, że status każdego bytu powinno się określać w odniesieniu do bytów wobec niego nadrzędnych (Schulz, 2009, s. 53-54). Otoczenie organizacji edukacyjnych jest niezwykle złożone, a tym samym znacznie zróżnicowane. Organizacja edukacyjna podlega wpływom elementów otoczenia ogólnego i systemowego. Otoczenie ogólne szkoły obejmuje różne sektory o charakterze społecznym, kulturowym, prawnym, ekonomicznym, politycznym, itd.) - czyli od społeczeństwa globalnego, geopolitycznego środowiska, po systemy społeczne środowiska lokalnego i rodziny. Środowisko geopolityczne obejmuje systemy polityczne, społeczne i ekonomiczne, które zajmują się polityką edukacyjną i wymaganiami edukacyjnymi lub wpływają na tę politykę i wymagania oraz odgrywają istotną rolę w dostarczaniu zasobów dla systemów edukacji. $Z$ kolei środowisko (otoczenie) systemowe wiąże się z usytuowaniem organizacji edukacyjnej ze względu na typ potrzeb edukacyjnych, jakie zaspokaja i tym samym określa, jakie jest jej miejsce w systemie oświaty.

Roman Schulz zwraca uwagę na trzy zasadnicze słabości analizy szkoły. Pierwsza z nich dotyczy postrzegania szkoły, której nie rozpatrujemy całościowo, w powiązaniu ze zjawiskami społecznymi oraz oświatowymi. Współczesna wizja szkoły wciąż ma charakter wyizolowany, nie uwzględniający jej roli jako agencji socjalizacyjnej (Schulz, 1992, s. 35). Jest to instytucja związana z innymi instytucjami, a jednocześnie wykonująca specjalne zadania edukacyjne, zatem wyjątkowa w ramach całości wszystkich form przekazu kulturowego. Drugim mankamentem według autora jest atomizm, który powoduje, że szkoły nie analizuje się w sposób systemowy, a także nie postrzega się jej jako zorganizowanej całości i elementu nadsystemu. Trzecia słabość odnosi się do 
ujęcia szkoły rozumianej w kategoriach statycznych, bez uwzględnienia jej roli w budowaniu zmiany, jako instytucji rozwijającej się i przeobrażającej, zmienianej oraz samorozwijającej się (Schulz, 1992, s. 5-6). Słabości te wydają się być wciąż aktualne, prowokując fragmentaryczne postrzeganie szkoły, a tym samym powodując nieskuteczność działań oświatowych. Owa nieskuteczność, pozorność działań oświatowych jest obszarem zainteresowania wielu badaczy i badaczek w obszarze nauk humanistycznych i społecznych, w tym także w pedagogice.

Z kolei Bogusław Śliwerski upatruje słabości systemu edukacji w nieudolności władz oświatowych, przypadkowości działań, biurokratyzacji, braku uspołecznienia szkół. Polityka edukacyjna, jak i wszystkie decyzje oświatowe na wyższych szczeblach, mają swoje konsekwencje dla lokalnych środowisk szkolnych.

[...] Polska oświata wciąż tkwi w biurokratycznym i etatystycznym modelu zarządzania, w którym dominują odgórnie ustanowione struktury oraz bieżące, doraźne, oparte na władczych postawach osób sprawujących władzę (autorytaryzm, nieustanne kontrolowanie podwładnych, brak zaufania, nieprzejrzystość postępowania i chaos kompetencyjny, itp.) sterowanie podmiotami edukacji [...]. (Śliwerski 2009, s. 318-319).

Zbigniew Kwieciński wskazuje natomiast na kryzys trzech podstawowych funkcji szkoły: rekonstrukcyjnej, adaptacyjnej oraz emancypacyjnej. Jego zdaniem szkoła wypełnia zadania w ramach każdej z tych funkcji źle. Rekonstrukcja ma charakter wybiórczy i niepełny, adaptacja jest nie tylko niepełna, ale i pozorna, bowiem istniejące w szkole struktury mają charakter udawany i nieprawdziwy. Uczniowie nie nabywają w szkole także kompetencji przekraczania granic i wychodzenia poza te struktury (Kwieciński, 1995, s. 21-22). Na pozorność działań edukacyjnych wskazują również Maria Dudzikowa i Karina Knasiecka-Falbierska (2013) w książce pt. Sprawcy i/lub ofiary działań pozornych w edukacji szkolnej, Dudzikowa przyjmuje tezę, że:

działania pozorne w systemie oświaty generując rozbieżność celów i funkcji założonych z realizowanymi oraz $\mathrm{z}$ intencjami i działaniami potencjalnych aktorów i ich gremiów (czy to w płaszczyźnie makro- czy w mikro-) stają się jednym ze źródeł braku postępu w reformowaniu szkolnictwa i zarazem źródłem atrofii zaangażowania różnych podmiotów w jego zmianę (Dudzikowa, 2013, s. 34-35). 
Poparciem dla tej tezy są, zawarte we wskazanej wyżej publikacji, diagnozy i egzemplifikacje działań pozornych w edukacji. Różni autorzy i autorki zastanawiają się nad ich mechanizmami i skutkami, możliwościami i barierami w zakresie ich likwidacji. Obraz edukacji, który wyłania się z tych analiz jest dość negatywny. Edukacja jawi się jako obszar licznych zabiegów pozornych zarówno na poziomie politycznym, ministerialnym, prawno-organizacyjnym, jak i na poziomie praktyki edukacyjnej.

Cytowana książka stanowi inspirację dla prezentowanego artykułu. Niniejszym „dorzucamy” (uszczegółowiamy) kolejny pozór w edukacji - pozór tkwiący w obszarze podstaw programowych kształcenia ogólnego.

\section{Pozór podstaw/pozór w podstawach programowych kształcenia ogólnego}

Ustanawiane przez państwo $\mathrm{w}$ formie aktu prawnego podstawy programowe kształcenia ogólnego są z jednej strony wyrazem polityki państwa w stosunku do szkoły i edukacji, z drugiej strony - poprzez fakt obowiązywania - wpływają w sposób zasadniczy na kształt szkolnej edukacji zarówno na poziomie organizacyjnym, jak i wychowawczo-dydaktycznym. W związku z powyższym analizowanie podstaw programowych, jako obszaru potencjalnego pozorowania działań, można także ująć z dwóch perspektyw:

1. Podstawy programowe jako efekt potencjalnego pozoru polityki oświatowej. W tym sensie mogą być przykładem działań pozornych na poziomie państwowym. Stanowią wówczas pole badawcze, dla którego kontekstem jest polityka oświatowa.

2. Podstawy programowe jako źródło pozoru w praktyce edukacyjnej. Takie rozumienie oznacza z kolei, że określony kształt podstawy programowej wymusza/doprowadza/stwarza podatny grunt/ułatwia pojawienie się potencjalnych działań pozornych w praktyce edukacyjnej. Podstawy programowe stanowią zatem obszar zainteresowań badawczych jako kontekst dla praktyki edukacyjnej.

Obie perspektywy są ze sobą ściśle powiązane, a ich dostrzeganie pozwala uniknąć tej słabości w analizowaniu szkoły, którą Roman Schulz określa mianem atomizmu. Badania mogą przy tym „ciążyć” bardziej w kierunku jednej lub drugiej perspektywy, ale dla całościowego ujęcia problematyki ważne jest, by owo drugie ujęcie (tu rozumiane jako odmienne od tego, które stanowi centralny obszar zainteresowań dla danego badacza/ki) pozostawało chociażby „na zapleczu”. Doskonale to widać w konkretnych egzemplifikacjach badań z tego obszaru. 
I tak druga perspektywa jest punktem centralnym dla analizy Iwony Kopaczyńskiej (2013, s. 221-239), która wskazuje, jakie skutki dla edukacji ma kształt podstawy programowej dla pierwszego etapu edukacyjnego. Dostrzega tam przede wszystkim następujące obszary pozoru:

- pozór budowania uczącej się wspólnoty - podczas gdy realizacja tak „skrojonej” podstawy programowej skoncentrowana jest na indywidualnych efektach uczenia się;

- pozór przygotowania szkoły na zróżnicowane potrzeby uczniów i uczennic - podczas gdy w praktyce edukacyjnej to uczniowie i uczennice musza być gotowi, by spełnić jednolite wymagania edukacyjne;

- pozór aktywności poznawczej uczniów i uczennic - podczas gdy kształt podstawy programowej wskazuje raczej na ich praktyczną tresurę (Kopaczyńska, 2013, s. 224-235).

Jednocześnie, przy artykulacji powyższych pozorów, autorka dostrzega szerszy kontekst społeczno-polityczny, którego wyrazem jest właśnie analizowana podstawa programowa.

Powiązanie między obiema perspektywami dostrzega też Maria Groenwald (2013, s. 133-136), która zwraca między innymi uwagę na pozorność deklaracji wynikających z ustawy z dnia 7 września 1991 r. o systemie oświaty (t.j. Dz.U z 2015 r. poz. 2156 ze zm.) w odniesieniu do praktycznych działań szkoły, ale też na niespójności między owymi deklaracjami, a tym, co de facto wynika z podstaw programowych.

Powyższe perspektywy są również dostrzegane przez Mariolę Chomczyńską-Rubachę (2010, s. 147-161), która koncentrując się na podstawie programowej do przedmiotu wychowanie do życia w rodzinie, nie przyjmuje wprawdzie perspektywy pozoru, ale analizuje ją przy uwzględnieniu kontekstu kulturowo-społecznego oraz standardów rozwojowych. Oznacza to w rezultacie ciążenie w kierunku pierwszej perspektywy (analiza podstawy programowej w oparciu o podstawy teoretyczne edukacji seksualnej oraz w kontekście dyskursów seksualności obecnych w przestrzeni publicznej), ale z wnioskami istotnymi dla perspektywy drugiej.

W niniejszym artykule poruszamy się także między wskazanymi wyżej dwiema perspektywami analizowania podstaw programowych. Nasze analizy zmierzają bardziej w kierunku perspektywy pierwszej. Wynika to ze specyfiki, a zwłaszcza metodologii przeprowadzonych badań. Jako przykład wybrałyśmy podstawę programową do trzeciego etapu edukacyjnego (gimnazjum). Stawiamy tezę, że pozorem jest to, jakoby podstawa programowa miała zakładać deklarowany przez dokumenty europejskie rozwój kompetencji społecznych 
i obywatelskich u uczniów i uczennic. Nie chodzi nam zatem o to, czy kompetencje społeczne i obywatelskie są rozwijane u uczniów i uczennic na poziomie gimnazjalnym. Chodzi nam o to, czy w ogóle ich rozwijanie (systematyczne, „zrównoważone”, uwzględniające obszar wiedzy, umiejętności i postaw) jest zakładane na poziomie podstaw programowych.

\section{Zarys założeń metodologicznych}

Przedstawione w ramach artykułu wyniki badań pochodzą z szerszego projektu badawczego, którego celem była identyfikacja i ocena kompetencji społecznych i obywatelskich zawartych $\mathrm{w}$ podstawach programowych kształcenia ogólnego oraz ocena tak sformułowanych podstaw programowych dla edukacji (Kopińska, Solarczyk-Szwec 2016; Solarczyk-Szwec, Matusiak, Kopińska 2016; Symonowicz-Jabłońska, Wieczór, 2016; Kopińska, Majchrzak, Szwech 2017). Badanie zostało przeprowadzone przez Katedrę Pedagogiki Szkolnej Wydziału Nauk Pedagogicznych Uniwersytetu Mikołaja Kopernika w Toruniu w roku 2015.

W badaniach posłużono się metodą zbierania danych - przeszukiwaniem źródeł wtórnych (Rubacha, 2008, s. 157-164). Przedmiotem analizy były podstawy programowe kształcenia ogólnego dla wszystkich etapów edukacyjnych, a jednostką analizy wymaganie szczegółowe. Na potrzeby badań skonstruowano katalog 116 kategorii analitycznych. Kategorie te zostały utworzone na podstawie kodowania $\mathrm{z}$ teorii ${ }^{1}$ i kodowania otwartego (Gibbs, 2011, s. 90-93; Rubacha, 2008, s. 263-265), ale także kodowanie z dokumentów polityczno-oświatowych ${ }^{2}$, co ma szczególne znaczenie w kontekście podejmowanej tu problematyki. Stworzone kategorie ukonstytuowały zatem potencjalną listę efektów uczenia się odnoszących się do kompetencji społecznych i obywatelskich. W badaniach analizowano wszystkie wymagania szczegółowe z podstaw

1 Wykorzystano tu m.in.: Martowska K., Matczak A., Pomiar kompetencji spolecznych prezentacja nowego narzędzia diagnostycznego, w: „Psychologia Jakości Życia”, 2013, 1., Matczak A., Kwestionariusz kompetencji spolecznych, Warszawa 2007, Riggio R.E., Assesment of basic social skills, ,Journal of Personality and Social Psychology” 1986, nr 51, s. 649-660; Hoskins B., Villalba E., Van Niljen D., Barber C. (2008), Measuring Civic Competence in Europe, Luxembourg: Office for Official Publications of the European Communities.

2 Załącznik do Zalecenia Parlamentu Europejskiego i Rady z dnia 18 grudnia 2006 r. w sprawie kompetencji kluczowych w procesie uczenia się przez całe życie - Kompetencje kluczowe w uczeniu się przez całe życie - Europejskie Ramy Odniesienia (L/394), Polska Rama Kwalifikacji - Raport Referencyjny. Odniesienie Polskiej Ramy Kwalifikacji na rzecz uczenia się przez całe życie do Europejskiej Ramy Kwalifikacji. 
programowych, poszukując określonych kategorii analitycznych. W rezultacie ustalono, że w podstawach programowych kształcenia ogólnego obecne są 833 wymagania szczegółowe, które zawierają efekty uczenia się wpisujące się w kompetencje społeczne i obywatelskie. Przedstawione w tym artykule wyniki odnoszą się tylko do trzeciego etapu edukacyjnego. Podstawę programową dla tego etapu należy zatem potraktować jako fragment całego cyklu edukacji szkolnej, aczkolwiek również stanowiący określoną całość. Nadto należy podkreślić, że uzyskane tu wyniki korespondują w dużej części z tymi, które odnoszą się do całości podstaw programowych, obowiązujących na wszystkich etapach edukacyjnych (Kopińska, Solarczyk-Szwec, 2016; Kopińska, Majchrzak, Szwech, 2017).

Punktem odniesienia dla identyfikacji pozoru odnoszącego się do tego, że podstawy programowe kształcenia ogólnego zakładają rozwijanie kompetencji społecznych i obywatelskich u uczniów i uczennic, jest kilka faktów:

- po pierwsze - kompetencje społeczne i obywatelskie zostały wymienione przez Parlament Europejski i Radę Unii Europejskiej wśród kompetencji kluczowych, czyli takich, które są uznawane za konieczne „do osobistej samorealizacji, bycia aktywnym obywatelem, spójności społecznej i uzyskania szans na zatrudnienie w społeczeństwie wiedzy" (Zalecenie Parlamentu Europejskiego i Rady z dnia 18 grudnia 2006 r. w sprawie kompetencji kluczowych w procesie uczenia się przez całe życie - Kompetencje kluczowe w uczeniu się przez całe życie - Europejskie Ramy Odniesienia (L/394);

- po drugie - kompetencje te, zgodnie z powyższym dokumentem, są określane jako połączenie wiedzy, umiejętności i postaw, co ma również swoje przełożenie na ich szczegółowe definicje zawarte w Załączniku do powyższego Zalecenia;

- po trzecie - w uzasadnieniu do projektu rozporządzenia wprowadzającego obecnie obowiązujące podstawy programowe wskazano, że uwzględnia ono Zalecenia Parlamentu Europejskiego i Rady, o których mowa wyżej³

Należy przy tym podkreślić, że pomijamy w tym miejscu krytyczną analizę samego Zalecenia i jego Załącznika ${ }^{4}$. Interesuje nas przełożenie przyjętych regulacji na konkretny kształt podstawy programowej.

${ }^{3}$ http://bip.men.gov.pl/wp-content/uploads/sites/2/2008/12/projekt_rozporzadzenia_2008 1202_uzasadnienie.pdf, dostęp: 12.05.2016.

${ }^{4}$ Zob. na ten temat - Kopińska, 2014. 
Skoro kompetencje społeczne są połączeniem wiedzy, umiejętności i postaw, to interesującym będzie sprawdzenie, czy podstawa programowa artykułuje takie wymagania szczegółowe w ramach poszczególnych przedmiotów, które odnoszą się właśnie do wszystkich trzech obszarów. Czy uzyskane wyniki mogą upoważniać do wniosku o względnie „zrównoważonym” (przynajmniej w założeniu) rozwoju owych kompetencji?

Nadto uważamy, że istotne byłoby sprawdzenie, czy podstawa programowa dla trzeciego etapu edukacyjnego artykułuje takie wymagania szczegółowe, które wypełniają definicję kompetencji społecznych i obywatelskich z Załącznika do Zalecenia Parlamentu Europejskiego i Rady, o którym mowa wyżej. Ponieważ jednak, z jednej strony, dokument ów dotyczy uczenia się przez całe życie, $\mathrm{z}$ drugiej zaś zakres prezentowanych analiz jest w tym miejscu ograniczony rozmiarami tego artykułu, wybrałyśmy kilka kategorii analizy (tabela 1.), które są istotne z punktu widzenia rozwoju społecznego młodzieży gimnazjalnej, a które jednocześnie wpisują się w definicje wynikające z Zalecenia.

Tabela 1. Wybrane kategorie analityczne

\begin{tabular}{|c|l|}
\hline L.p. & \multicolumn{1}{|c|}{ Kategorie analityczne/efekty uczenia się } \\
\hline 1. & umiejętność współpracy i interakcji \\
\hline 2. & umiejętność konstruktywnego rozwiązywania problemów \\
\hline 3. & umiejętność rozwiązywania konfliktów \\
\hline 4. & umiejętność radzenia sobie ze stresem i frustracją i wyrażania ich w konstruktywny sposób \\
\hline 5. & umiejętność zachowania się w sposób asertywny, wyrażanie i odmawianie próśb \\
\hline 7. & umiejętność okazywania uczuć i empatycznego zachowania się \\
\hline 8. & $\begin{array}{l}\text { umiejętność uczestnictwa w demokratycznych procesach podejmowania decyzji w różnych środowi- } \\
\text { skach, np. w szkole }\end{array}$ \\
\hline 9. & umiejętność konstruktywnego porozumiewania się w różnych środowiskach \\
\hline 10. & gotowość do zaangażowania się w działania publiczne \\
\hline 11. & szacunek dla różnic, w tym różnic płciowych, religijnych i etnicznych \\
\hline 12. & negatywna ocena uprzedzeń, rasizmu i dyskryminacji oraz gotowość do pokonywania uprzedzeń \\
\hline 13. & gotowość zmiany własnej opinii i osiągania kompromisu \\
\hline
\end{tabular}

\section{Wyniki badań}

W podstawie programowej kształcenia ogólnego na trzecim etapie edukacyjnym zidentyfikowano 322 wymagania odnoszące się do kompetencji społecz- 
nych i obywatelskich. Wymagania z obszaru wiedzy stanowią $80,1 \%$ wszystkich wymagań, te z obszaru umiejętności stanowią $26,7 \%$, a odwołujące się do postaw tylko $7,5 \%{ }^{5}$. Na podstawie uzyskanego wyniku można stwierdzić, że $\mathrm{w}$ podstawie programowej gimnazjum dominuje wiedza, a umiejętności oraz postawy to niespełna jedna trzecia wszystkich analizowanych wymagań. Taki wynik może dziwić w kontekście debaty na temat kompetencji obywatela/obywatelki Europy, rozwoju umiejętności miękkich, kształtowania społeczeństwa obywatelskiego, a także wymogów rynku pracy, w ramach którego wiedza jest istotna tylko $\mathrm{w}$ powiązaniu $\mathrm{z}$ odpowiednimi umiejętnościami. Trudno także o internalizację wartości, które pozostają tylko na poziomie wiedzy, a mają małe szanse na zaistnienie w działaniach. Tymczasem na trzecim etapie edukacyjnym w podstawie programowej w zakresie kompetencji społecznych i obywatelskich wyartykułowano najwięcej wymagań szczegółowych odnoszących się do obszaru wiedzy. Umiejętności i postawy potraktowano zaś w sposób marginalny (Wykres 1.). Młodzież w tym okresie w sposób szczególny szuka swojego miejsca w świecie. Za Marią Tyszkową warto podkreślić, że okres dorastania jest niezwykle ważny dla aktywności człowieka, a duże znaczenie w tym czasie ma także działalność społeczna i samowychowawcza. Młodzież zaczyna się także kierować w stronę działań, które w sposób realny wpływają na otoczenie i życie człowieka (Tyszkowa, 1977). W związku z tym ta dysproporcja może zaburzać prawidłowy proces adaptacji do pełnienia roli ucznia/uczennicy, bycia częścią szkolnej społeczności, a w efekcie - społeczeństwa w ogóle.

Ponieważ szkolna edukacja w Polsce ma charakter przedmiotowy, wobec tego wymagania w podstawach programowych również są przypisane poszczególnym przedmiotom. Interesujący jest zatem fakt, czy kompetencje społeczne i obywatelskie na trzecim etapie edukacyjnym są artykułowane w wymaganiach szczegółowych wszystkich/większości przedmiotów? Czy też może koncentrują się w jakichś konkretnych? Analiza podstawy programowej dla gimnazjum wykazała, że zdecydowanie mamy tu do czynienia z przedmiotami dedykowanymi tym kompetencjom. Najwięcej badanych wymagań występuje w przedmiotach: wiedza o społeczeństwie oraz historia (Wykres 2). Według podstawy programowej pozostałe przedmioty wydają się pełnić znacznie mniejszą bądź wręcz marginalną (edukacja dla bezpieczeństwa, etyka, geografia, chemia) rolę w rozwoju kompetencji społecznych i obywatelskich. Należy również dodać, że w podstawie programowej niektórych przedmiotów badane kompetencje nie występują wcale (muzyka, fizyka, biologia).

${ }^{5}$ Procenty nie sumują się do stu, ponieważ niektóre wymagania zakwalifikowano do więcej niż jednej kategorii. 


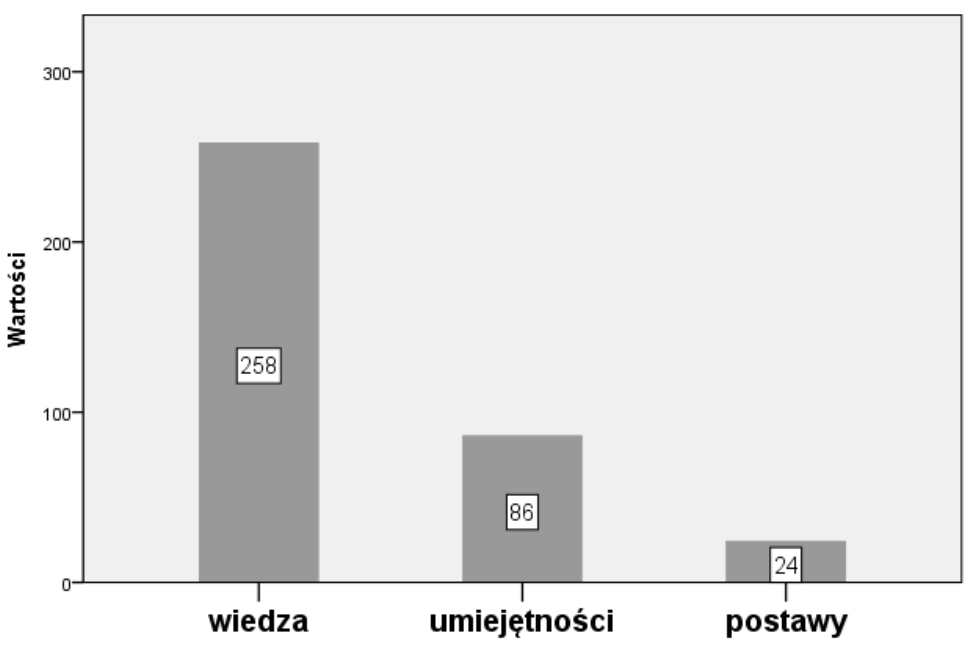

Wykres 1. Wymagania z podstawy programowej kształcenia ogólnego w gimnazjum z uwzględnieniem podziału na obszar wiedzy, umiejętności i postaw (zgrupowane)*

Źródło: badania własne.

Na wykresie nr 3 widoczne są różnice występowania wymagań w obszarze wiedzy, umiejętności i podstaw z uwzględnieniem podziału na przedmioty. Wyraźnie można tu dostrzec dysproporcje pomiędzy licznie reprezentowaną wiedzą, pojawiającymi się umiejętnościami i ledwie zauważalnymi postawami. Dominacja umiejętności występuje w podstawie programowej języka polskiego, a także języka obcego nowożytnego oraz informatyki. Wiedza zdominowała i kilkukrotnie przewyższyła umiejętności oraz postawy zakładane do osiągnięcia na zajęciach z wiedzy o społeczeństwie czy historii.

* Każde wymaganie szczegółowe z podstawy programowej (jednostka analizy) składało się z jednego, dwóch lub nawet kilku efektów uczenia się. Efekty uczenia się w ramach jednego wymagania szczegółowego mogły należeć do jednego obszaru (wiedzy, umiejętności lub postaw), do dwóch lub kilku. Na wykresie przedstawiono podział wymagań z podstawy programowej w sposób zgrupowany, tzn. np. wymaganie z podstawy programowej, które łączy efekty uczenia się z obszaru wiedzy z obszarem umiejętności, zostało zaklasyfikowane zarówno do obszaru wiedzy, jak i do obszaru umiejętności. $Z$ tego też powodu liczebności wymagań na wykresie 1 nie sumują się do liczby 322 . 


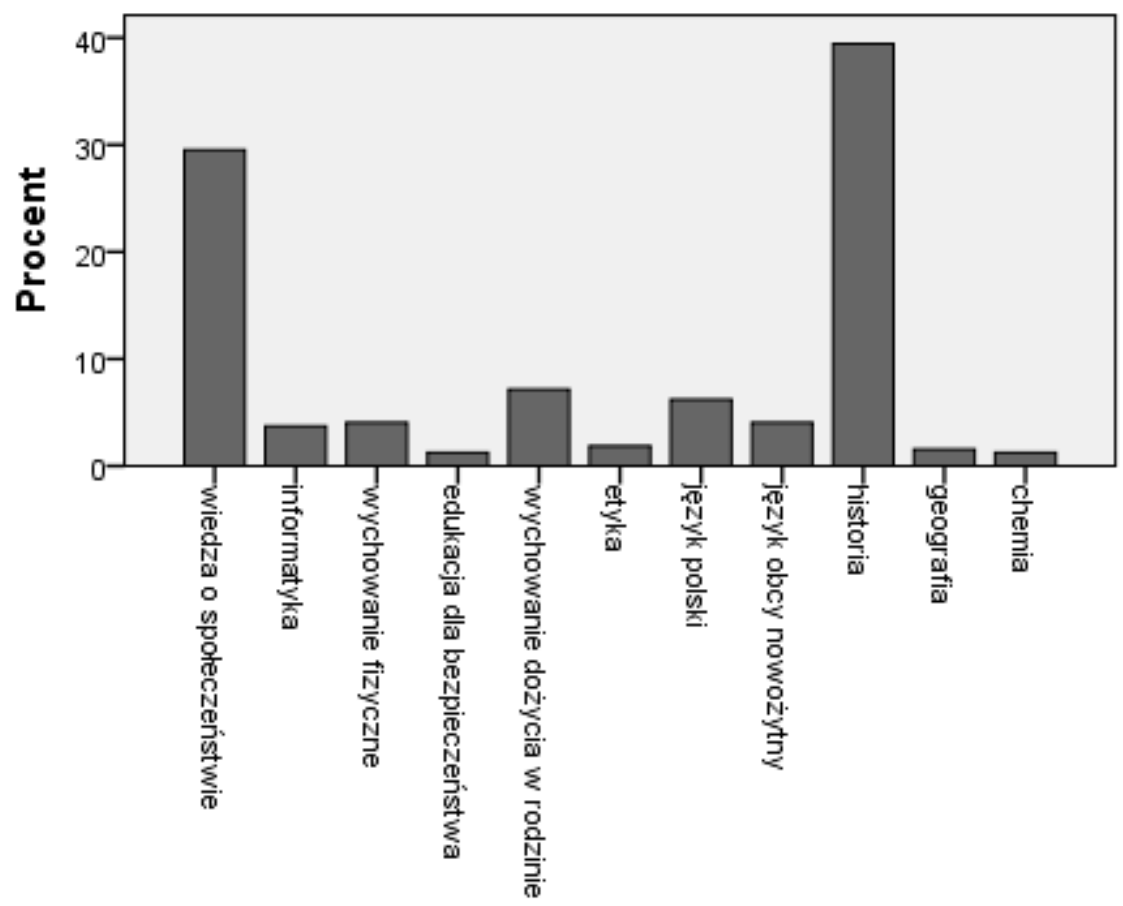

Wykres 2. Wymagania z podstawy programowej kształcenia ogólnego w gimnazjum z podziałem na poszczególne przedmioty

Źródło: badania własne.

Jednocześnie wykres 3 pokazuje, że wiedza o społeczeństwie jest przedmiotem, w którym odnajdziemy najwięcej wymagań odnoszących się do umiejętności i postaw mieszczących się w zakresie kompetencji społecznych i obywatelskich, nie zmienia to jednak faktu zdecydowanej dominacji wiedzy. Wykres ten pokazuje również, że największa liczba wymagań wpisujących się w kompetencje społeczne i obywatelskie, a pochodzących z obszaru wiedzy, jest zlokalizowana w historii. Okazuje się bowiem, że to, co dominuje w ramach wymagań w obszarze wiedzy, to wiedza na temat historii i dziedzictwa kulturowego krajowego i europejskiego. Założenie, że podstawa programowa rozwija kompetencje społeczne i obywatelskie jest zatem pozorem i to nie tylko dlatego, że mamy tu do czynienia z dominacją wiedzy, że nie ma choćby względnej równowagi między obszarem wiedzy, umiejętności i postaw. Jest również pozorem dlatego, że owa wiedza ma charakter jednostronny. Warto 


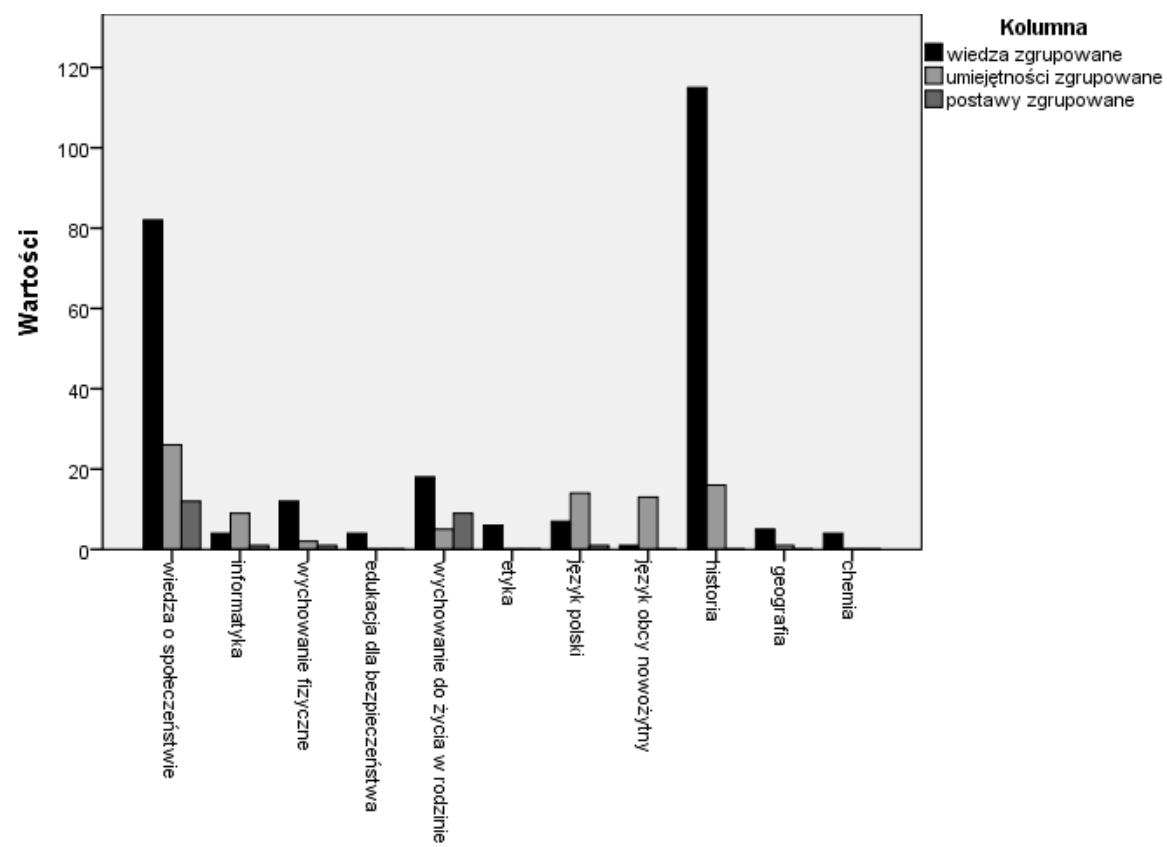

Wykres 3. Wymagania z podstawy programowej dla gimnazjum z podziałem na poszczególne przedmioty i obszary: wiedzy, umiejętności oraz postaw (zgrupowane).

Źródło: badania własne.

w tym momencie podkreślić, że ta sama tendencja jest wyraźnie identyfikowana nie tylko w podstawie programowej dla trzeciego etapu edukacyjnego, ale ogółem w całych podstawach programowych kształcenia ogólnego (Kopińska, Majchrzak, Szwech, 2017).

Sprawdźmy teraz, czy wśród wymagań szczegółowych określonych dla poszczególnych przedmiotów na etapie gimnazjalnym występują takie, które wpisują się w wybrane przez nas kategorie (Tabela 2).

Jak wynika z Tabeli 2, wymagania szczegółowe w podstawie programowej dla trzeciego etapu edukacyjnego, wyartykułowane dla poszczególnych przedmiotów nie zakładają w ogóle rozwijania takich umiejętności i postaw, jak: radzenie sobie ze stresem i frustracją, konstruktywne porozumiewanie się w różnych środowiskach, szacunek dla różnic czy gotowość zmiany własnej opinii i osiągania kompromisu. Pozostałe wybrane przez nas kategorie również nie mają dobrej reprezentacji. Warto przy tym dodać, że połowa wymagań ujętych w Tabeli 2 usy- 
tuowana jest $w$ ramach przedmiotu wiedza o społeczeństwie. Pozostałe występują w informatyce (umiejętność rozwiązywania problemów), wychowaniu do życie w rodzinie (umiejętność empatycznego zachowania się), języku polskim (umiejętność empatycznego zachowania się), języku obcym nowożytnym (umiejętność współpracy, umiejętność zachowania się w sposób asertywny).

Tabela 2. Występowanie wybranych kategorii analitycznych/efektów uczenia się w podstawie programowej dla trzeciego etapu edukacyjnego

\begin{tabular}{|l|c|c|}
\hline \multirow{2}{*}{ Kategorie analityczne/efekty uczenia się } & \multicolumn{2}{c|}{ N=322 } \\
\cline { 2 - 3 } & nie występuje & występuje \\
\hline umiejętność współpracy i interakcji & 320 & 2 \\
\hline umiejętność konstruktywnego rozwiązywania problemów & 319 & 3 \\
\hline umiejętność rozwiązywania konfliktów & 321 & 1 \\
\hline $\begin{array}{l}\text { umiejętność radzenia sobie ze stresem i frustracją i wyrażania ich } \\
\text { w konstruktywny sposób }\end{array}$ & 322 & 0 \\
\hline $\begin{array}{l}\text { umiejętność zachowania się w sposób asertywny, wyrażanie } \\
\text { i odmawianie próśb }\end{array}$ & 320 & 2 \\
\hline umiejętność okazywania uczuć i empatycznego zachowania się & 320 & 2 \\
\hline $\begin{array}{l}\text { umiejętność uczestnictwa w demokratycznych procesach podejmowania } \\
\text { decyzji w różnych środowiskach, np. w szkole }\end{array}$ & 321 & 1 \\
\hline $\begin{array}{l}\text { umiejętność konstruktywnego porozumiewania się w różnych } \\
\text { środowiskach }\end{array}$ & 322 & 0 \\
\hline gotowość do zaangażowania się w działania publiczne & 321 & 1 \\
\hline szacunek dla różnic, w tym różnic płciowych, religijnych i etnicznych & 322 & 0 \\
\hline $\begin{array}{l}\text { negatywna ocena uprzedzeń, rasizmu i dyskryminacji oraz gotowość do } \\
\text { pokonywania uprzedzeń }\end{array}$ & 320 & 2 \\
\hline gotowość zmiany własnej opinii i osiągania kompromisu & 322 & 0 \\
\hline
\end{tabular}

Źródło: badania własne.

Wskazane w tabeli 2 umiejętności i postawy są istotne z punktu widzenia rozwoju społecznego w okresie wczesnej adolescencji. Nie twierdzimy, że szkoła nie rozwija tych umiejętności i postaw. Nie mamy bowiem podstawy do tego, by taki wniosek skonstruować. Skoro jednak są to kompetencje ważne rozwojowo, a jednocześnie zdecydowanie wpisują się w definicję kompetencji społecznych i obywatelskich, sformułowaną w Załączniku do Zalecenia Parlamentu Europejskiego i Rady z dnia 18 grudnia 2006 r. w sprawie kompetencji kluczowych w procesie uczenia się przez całe życie (które zostało uwzględnione przy konstruowaniu podstaw programowych kształcenia ogólnego), to 
powinny tam mieć swoją „,dobrą” reprezentację. Tak jednak nie jest. I jest to kolejne uzasadnienie pozoru podstawy programowej.

\section{Podsumowanie i wnioski}

Przytoczone wyżej wyniki potwierdzają tezę o pozorze podstawy programowej. Pozór ten polega na przyjęciu Zalecenia Parlamentu Europejskiego i Rady z dnia 18 grudnia 2006 r. w sprawie kompetencji kluczowych w procesie uczenia się przez całe życie oraz Europejskiej Ramy Kwalifikacji (Góralska, Solarczyk, 2012) i uwzględnieniu ich w podstawach programowych. Kazus podstawy programowej dla trzeciego etapu edukacyjnego pokazuje, że nie jest to prawdą. Podstawa programowa dla gimnazjum nie zakłada rozwijania kompetencji społecznych i obywatelskich uczniów i uczennic, a przynajmniej nie w takim kształcie, jak wynika to z ich „europejskich” definicji. W Polsce uczniowie i uczennice mają przede wszystkim posiadać wiedzę z tego zakresu i to przede wszystkim... historyczną. W okresie wczesnej adolescencji nie są ważne umiejętności związane z empatią, asertywnością, konstruktywnym porozumiewaniem się w różnych środowiskach i osiąganiem kompromisu. Trudno wnioskować, by podstawa programowa zakładała, że demokracja jest projektem otwartym, wiąże się z rozwojem, a w związku z tym istotne jest ćwiczenie kompetencji demokratycznych (Błajet, Przyborowska, 2014, s. 82). Nie mają tu znaczenia wyniki Diagnozy Społecznej wskazujące na niewielkie oznaki budowy w Polsce społeczeństwa obywatelskiego i spadek wskaźników kapitału społecznego (Czapiński, Panek 2015). Nie przywiązuje się zatem nadmiernej uwagi do umiejętności uczestnictwa w demokratycznych procesach podejmowania decyzji, np. w szkole, umiejętności współpracy czy szacunku dla różnic. Jaki może być tego skutek dla praktyki edukacyjnej? Nadzieja leży po stronie świadomych nauczycieli i nauczycielek, którzy będą starali się kształtować „deficytowe” kompetencje społeczne i obywatelskie. Ale nadzieja ta jest nikła i to nie z powodu braku wiary w środowisko nauczycielskie. Ich możliwości działania są również ograniczone dysfunkcjonalnością prawa oświatowego (Kopińska, 2013), które wymusza kolejne pozory oraz urynkowieniem edukacji (Potulicka, 2010), co doprowadza do redukcji pola myślenia o edukacji (Szkudlarek, 2005), sprowadzając ją do tego, że liczy się w zasadzie tylko to, co jest na egzaminach (Dobrołowicz, 2013, s. 178). Ta ostatnia kwestia jest bardzo niepokojąca w kontekście przedstawionych w tym artykule wyników badań. Jeżeli liczy się tylko to, co ma związek z egzaminami, to - po pierwsze „źle to wróży” kompetencjom społecznym i obywatelskim w ogóle, a po drugie - oznacza koncentrację edukacji szkolnej na 
szczegółowych wymaganiach przedmiotowych, a nie na rozwijaniu kompetencji nieobecnych czy „słabo sprawdzalnych” w formie egzaminacyjnej. Przecież nie da to sukcesu ani szkole, ani nauczycielom, ani uczniom.

\section{Bibliografia}

Błajet P., Przyborowska B. (2014), Kształtowanie kompetencji demokratycznych-perspektywa rozwojowa, „Studia Edukacyjne”, nr 30.

Chomczyńska-Rubacha M. (2010), Standardy rozwojowe edukacji seksualnej, w: „Studia Edukacyjne", nr 12, s. 147-161.

Czapiński J. Panek T. (red.) (2015), Diagnoza Spoleczna 2015. Warunki życia i jakość Polaków, Warszawa: Rada Monitoringu Społecznego, pobrano z: http://www.diagnoza. com/pliki/raporty/Diagnoza_raport_2015.pdf, dostęp: 13.04.2016.

Dobrołowicz J. (2013), Obraz edukacji w polskim dyskursie prasowym, Oficyna Wydawnicza „Impuls”, Kraków.

Dudzikowa M. (2013), Użyteczność pojęcia działań pozornych jako kategorii analitycznej. Egzemplifikacje z obszaru edukacji (i nie tylko), w: M. Dudzikowa, K. Knasiecka-Falbierska (red.), Sprawcy i/lub ofiary działań pozornych w edukacji szkolnej, pod red. M. Dudzikowej, K. Knasieckiej-Falbierskiej, Oficyna Wydawnicza „Impuls”, Kraków.

Gibbs G. (2011), Analizowanie danych jakościowych, Wydawnictwo Naukowe PWN, Warszawa.

Góralska R., Solarczyk-Szwec H. (2012), O kompetencjach w kontekście Polskiej Ramy Kwalifikacji dla uczenia się przez całe życie, „Edukacja Dorosłych”, nr 2 (67), s. 27-41.

Groenwald M. (2013), Standardy moralne czy standardy wymagań? O moralnych aspektach pozoru w szkole, w: M. Dudzikowa, K. Knasiecka-Falbierska (red.), Sprawcy i/lub ofiary działań pozornych w edukacji szkolnej, Oficyna Wydawnicza „Impuls”, Kraków.

Jagiełło-Rusiłowski A., Solarczyk-Szwec H. (2014), Kwarenda badań nad kompetencjami społecznym w Poslce i na świecie w kontekście akademickiej edukacji dorostych, „Przegląd Badań Edukacyjnych", nr 2 (17), s. 27-51.

Kopaczyńska I. (2013), Podstawa programowa dla klas I-III Szkoły Podstawowej jako punkt wyjścia działań pozornych, w: M. Dudzikowa, K. Knasiecka-Falbierska (red.), Sprawcy i/lub ofiary działań pozornych w edukacji szkolnej, Oficyna Wydawnicza „Impuls”, Kraków.

KopińskaV. (2013), Rekonstrukcja kultury prawnej szkoły na podstawie (zmian) przepisów prawnych w zakresie nadzoru pedagogicznego, „Przegląd Badań Edukacyjnych”, nr 17 (2). 
Kopińska V., Solarczyk-Szwec H. (2016), Edukacja dla wspólnoty? Krytyczna analiza podstaw programowych kształcenia ogólnego, „Forum Oświatowe”, nr 1, s. 11-32.

Kopińska V., Majchrzak K., Szwech A. (2017), Patriotyzm w edukacji szkolnej. Założenia podstaw programowych kształcenia ogólnego, „Teraźniejszość - Człowiek - Edukacja”, nr 1 ( w druku).

Przyborowska B. (2013), Pedagogika innowacyjności. Między teoria a praktyka edukacyjna, Wydawnictwo Naukowe UMK, Toruń.

Potulicka E. (2010), Wolny rynek edukacyjny a zagrożenia dla edukacji, w: E. Potulicka, J. Rutkowiak, Neoliberalne uwikłania edukacji, Oficyna Wydawnicza „Impuls”, Kraków.

Rubacha K. (2008), Metodologia badań nad edukacja, Wydawnictwa Akademickie i Profesjonalne, Warszawa.

Schulz R. (1992), Szkoła, instytucja, system, rozwój, Wydawnictwo „Edytor”, Toruń.

Schulz R. (2009), Wykłady z pedagogiki ogólnej, t. III: Logos edukacji, Wydawnictwo Naukowe UMK, Toruń.

Solarczyk-Szwec H. (2007), Edukacja obywatelska młodzieży i dorostych wobec przemocy politycznej-działania na pograniczu aktywności społecznej, oświatowej i kulturalnej, w: „Rocznik Andragogiczny”, Wyd. ITEE, Warszawa, s. 163-188.

Solarczyk-Szwec H. (2013), Walidacja kompetencji społecznych w kontekście Krajowych Ram Kwalifikacji dla Szkolnictwa Wyższego, nr 5 (52), s. 4-14.

Solarczyk-Szwec H., Matusiak A., Kopińska V. (2016), Kompetencje społeczne na wejściu $w$ dorosłość. Krytyczna analiza podstawy programowej kształcenia ogólnego dla IV etapu edukacyjnego, „Edukacja Dorosłych”, Nr 2/2016.

Symonowicz-Jabłońska I., Wieczór E. (2016), Budowanie kapitału społecznego w świetle analizy podstawy programowej dla pierwszego etapu edukacyjnego, „Problemy Wczesnej Edukacji”. Nr 4 (35).

Szkudlarek T. (2005), , Koniec pracy” czy koniec zatrudnienia? Edukacja wobec presji światowego rynku, w: A. Kargulowa, S.M. Kwiatkowski, T. Szkudlarek (red.), Rynek i kultura neoliberalna a edukacja, Oficyna Wydawnicza: „Impuls”, Kraków.

Śliwerski B. (2009), Problemy współczesnej edukacji. Dekonstrukcja polityki oświatowej III RP, Wydawnictwo Akademickie i Profesjonalne, Warszawa.

Tyszkowa M. (1977), Aktywność i działalność dzieci i młodzieży, Wydawnictwa Szkolne i Pedagogiczne, Warszawa. 